\section{Artificial Wool Production in Italy}

THE manufacture of artificial wool from milk has been successfully started in Italy, and the product known as Lanital has been shown to possess properties suitable for the textile industry. Ninety-four tons of Lanital were produced in 1936 and 760 tons in the first seven months of 1937. The process is based on a patent taken out in 1935 by Comm. Antonio Ferretti, and the plant as installed at the factory of Snia Viscosa at Milan is described in an illustrated article in Engineering of December 17. In the process, milk is first deprived of most of its cream, and then chemically treated to coagulate the casein. From vats the casein is transferred to tanks in which are placed water and certain solvents, the result being a viscous substance which can be made into fibres by squirting through fine holes in a spinning nozzle. After passing through an alkaline bath, the fibres in bundles are cut into 'flocks' which after further treatment are dried in steam-heated drying machines, the material then being ready for spinning and weaving into fabrics. It is stated that 'Lanital' has higher heat retaining properties than natural wool and that it can be boiled without loss of weight. Though established to render Italy free from the necessity of relying on outside supplies of raw material, purchases of casein are already being made from Holland and Denmark. It is, however, estimated that the country can supply 20-25 per cent of its wool requirements. At a recently opened exhibition in Rome, a whole pavilion is devoted to the Lanital industry.

\section{Scandinavian Influence in Northumbrian Art}

Scandinavian influence, owing to the Norse occupation, left a deep-seated and long-persistent mark on the life and culture of northern England, which is especially to be noted in art motifs and decorative design at the close of the first and beginning of the second millennia of our era. An interesting and instructive example of this influence is to be seen in the crozier of Bishop Ranulf Flambard, who died in 1128, and whose tomb on the site of the Chapter House of Durham Cathedral was opened in 1878. With his body were found the remains of a pewter chalice, his sapphire ring and his pastoral staff. The ring and staff were exhibited by Mr. T. D. Kendrick at the Society of Antiquaries on December 16. The wood of the staff has perished, but there remains the crook and ferrule of iron. The crook was silver-plated, and had been cleverly and delicately chased with an interlace of slender serpents, the design being inlaid in niello. As Mr. Kendrick pointed out, Flambard had so far identified himself with northern England as to adopt for his crozier the hard and economical ecclesiastical art of Northumbria in preference to the richer style of southern England. Mr. Kendrick went on to show that this ornament was in the characteristic eleventh century Viking style, and must have been made by a smith well practised in making the silver-plated spearheads with niello design of serpents and scrolls, which come chiefly from the Baltic lands. Some of such spearheads had been found in England, and there was little doubt that Flambard's staff had been made by a Northumberland smith. Though the design was Scandinavian in style and feeling, in detail it showed certain marked peculiarities, which must be regarded as northern English, since they could be explained only as due to a long-established English manuscript style. They were not found in purely Scandinavian art. There was additional evidence for this AngloScandinavian style, as for example in architectural detail at Kirkburn in Yorkshire, which helped to prove its general diffusion.

\section{Health Legislation in Industry}

Dr. LeONARD P. LockHart opened a discussion on the "Wider Issues of Health Legislation in Industry" in the Section of Medical Sociology at the recent annual meeting of the British Medical Association held at Belfast (Brit. Med. J., September 25, 1937). He said that the new Factories Act, in spite of omissions and shortcomings, represents a very considerable advance in social legislation. While certain provisions will act automatically to improve health and safety, there are others that will depend on a high level of co-operation and of common consent to make the result effective. He pointed out the important part played by voluntary effort preceding the consolidation by law. For example, individual employers have done a considerable amount of experimental work in industrial health, and much of what is known as industrial welfare has proved so valuable that it has now ceased to be voluntary and is to become an obligation. The voluntary activity of progressive employers, aided by the trade unions, has provided the necessary data to form a basis of the new industrial law.

Tнस Act as it is pegs industrial health and welfare at a higher level than ever before, but it should not be assumed that nothing remains to be done. The long fight to obtain recognition of society's duty to its members is all but won; the next task will be more laborious, and it will lack the spectacular victories of the earlier political struggles. Nor must it be thought that the responsibilities of the employer are ended when he has fulfilled the letter of the law. Many of the wider issues of industrial health, such as the psychoneuroses and emotional disturbance, with their physical sequelæ, arise not out of unhealthy conditions as commonly understood; but out of methods of work, methods of selection of staff, systems of supervision, payment and incentives, and Dr. Lockhart suggests that some form of statutory advisory board might be desirable, since it would be free to raise and discuss these matters before they became political questions. $\mathrm{He}$ also advocates an industrial training for doctors as a post-graduate course. The paper raises many important issues, and is worthy of very careful consideration.

\section{Control of Public Lighting}

ON December 10, Mr. J. M. Kennedy, Electricity Commissioner, inaugurated the 'Actadis' system for the ripple control of the public lighting of Maidstone. This is the latest development of a method which 
began with the lamplighter going his rounds with his pole. The method is the distribution of high-frequency A.c. ripples over the electric supply network from a central transmitting apparatus. The high-frequency machine which generates the current injected at various points into the network is rated at 30 kilowatts, and its frequency can be varied between 300 and 900 . They are injected directly on to the 6,600 volt A.c. system and actuate relays on the low-tension side. As condensers are placed in the high-frequency circuits, the power consumption is small. At present there are about 500 relays installed for the control of the lamps. The great advantage of the system is that the whole street lighting of a city can be switched on or off by actuating push buttons at a central point. If this system were adopted in a city, every street lamp could be extinguished within a few seconds of warning of an emergency being received. The system can also be used to control part of a load, for example the load required for the 'water heaters', for a short time so as to prevent the maximum load, as shown by the 'maximum indicator' being exceeded. The system was installed in Maidstone by Actadis Ltd., Vincent House, Vincent Square, S.W.I. The bulk of the apparatus is manufactured in Great Britain.

\section{Coloured Roads}

Is Roads and Road Construction of October $1 \mathrm{Mr}$. C. W. Manlove considers the question of whether it would not sometimes be advisable, instead of having a mass of signs at the side of the road, to colour the traffic lanes with various colours. A good driver looks at the road surface ahead, and should not be distracted by having to decipher road signs, a necessity which is sometimes contributory to accidents. If the road surface had a tinted colour when the speed limit changed, the driver would automatically notice that he was entering or leaving a controlled area. The coloured road has for several years been a common feature in the United States. This is probably due to the fact that in America many of the roads are made of concrete ; in Great Britain concrete roads are only beginning to be made. Recent official tests on the main Bath Road prove that a concrete road has a very long life. It has been computed that if the load does not exceed 15,000 tons of traffic a day, to wear the surface down one inch would take 200 years. The Cement Marketing Board estimates that the cost of tinting the top of a cement carriage road to the depth of two inches, supposing the road to be 30 feet broad, would be about $£ 250$ per mile. As international colours are used for colouring electrical engineering diagrams, the day may come when international colours will be used on the surfaces of the roads for warning and directing chauffeurs when danger is ahead and a change of speed is necessary.

\section{The Cross-Channel Ferry Service}

THE cross-channel ferry service between Dover and Dunkerque has now been in operation since October 1936. The three ferry steamers engaged in the service carry passengers between Great Britain and
Europe in through sleeping cars. Recently a special ramp has been built which enables motorists to drive straight into the special garage on board the ship, which has accommodation for twenty-five cars. It is not necessary to empty the petrol tanks of the cars before boarding the ship as special fireproof construction has been adopted. The new ramp is a reinforced concrete structure at the side of the ferry dock and there is a portcullis type of transfer bridge which is lowered on to the deck of the ship. The length of each of the ferry steamers is 360 feet and the beam is 63 feet. It is provided with twin screws each driven by a Parsons steam turbine through single reduction gearing. The normal speed is $16 \frac{1}{2}$ knots and the total horse-power is 4,900. It takes 500 passengers, 12 sleeping cars (or forty goods wagons) and 25 cars in the garage. The British Engineers' Export Journal of August states that the traffic carried by the train ferry is very varied. To the engineering exporter this ferry service is of great value, since heavy and awkward pieces of machinery can be loaded on a truck at Victoria and need suffer no transhipment until they arrive at a destination on the Continent. Up to May 31 of this year, the ferry service conveyed 9,577 loaded wagons, and during the same period 12,277 tons of merchandise were conveyed in through trucks from Dover to Dunkerque, and 23,288 tons were carried in the reverse direction.

\section{Forestry Research in Malaya}

THE Research Institute of the Forestry Department of the Federated Malay States has now been in existence for some years and is carrying out investigations of varying types which should have considerable importance for the improvement of the forests of the country. The Institute is organized on the lines of the Imperial Forest Institute at Dehra Dun in India, the branches consisting of sylviculture, botanical, wood technology, timber mechanics, seasoning, preservation and durability of timbers and entomology. Chemical investigations affecting forestry are undertaken by the Chemical Division of the Department of Agriculture, a grant being made by the Forest Department for this purpose. The Institute works in collaboration with Princes Risborough and also with the Malayan Railway Department and with the Civil Engineer, H.M. Naval Base, Singapore. The Forest Botanist, whilst on leave, spent some time working on a collection of Malayan specimens at Kew, where, by the courtesy of the director, he was accorded assistance by the Kew Herbarium staff. An item of botanical interest is mentioned in the annual report for 1936 (Forest Research Institute, Kepong, 1936) referring to the Gunong Tahan Expedition. The collection made includes 144 numbers, mainly from the open padang of the mountain tops. Although this collection has not yet been completely worked through, it is said that "it is evident that, though it contains very little that is new, it includes some nice material of rare species known only from this locality, e.g. Agathis flavescens, Ridl. and Gentiana malayana, Ridl." 